\title{
The Influence of the Arabian Nights on Modern Young Adult Literature: Midwinter Blood and in Darkness as Examples
}

\author{
Brahim Bouali \\ University of North Carolina, United States of America \\ E-mail: bbouali@uncc.edu
}

Received: 05-04- 2015

Published: 01-11- 2015
Accepted: 29-06- 2015

doi:10.7575/aiac.ijalel.v.4n.6p.84
Advance Access Published: August 2015

URL: http://dx.doi.org/10.7575/aiac.ijalel.v.4n.6p.84

\begin{abstract}
Derrida and Blanchot ${ }^{1}$ may be right when they consider genre as an imposition on a text. They seem to agree that a text achieves its singularity status only by "exceeding genre conventions". They are also compelling when both of them, though in different ways, speak about the death of the author, the omniscient divine figure behind the text. Barthes proposes the name of the "scriptor" to replace the authoritarian authority of the "author"; whereas Blanchot goes deeper and implies that the moment of death of the author is the very moment of his immortality. Any hint of labeling or categorization limits the text and leaves the door open to the Gramscian notion of hegemony or the Foucauldian concept of power. The endeavor in this small paper, the Influence of the Arabian Nights on Young Adult Literature, is based on Kristeva's/Barthes' notion of intertextuality ${ }^{2}$ and Foucault's discourse analysis. Intertextuality in the Barthian sense is based on a triangular relationship between the text, the reader and the potential other texts; whereas Foucault discourse analysis is based on five steps described in depth by Gavin Kendall; Gary Wickham (1999: 42). ${ }^{3}$ In this way my comparative analysis is no longer typological (based on category) but rather topological (based on degrees or continuum). In his "the literary mind', Mark Turner (1996) writes the following: "but not even she, meaning Shahrazad, for all her looking into the future, can know that her performance during the next thousand and one nights will bring her a reputation as the greatest literary mind ever" (P: 8). Turner 's compelling insight cannot be taken for granted if the main concern of the writer is to deconstruct the complex theme of story and projection in the parable from which, according to him, "we have a cognitive basis from which language can originate."(P: 168). The aim of this paper is to avoid the impressionism that may result from ad hoc personal opinion and consider the whole Arabian nights as a multidimensional genre or better canon genre from which artists continue to be inspired. The novelty in this study may be summarized in two points. First, it attempts to consider One Thousand and a Night as a canon genre that in a way proves the limitation of classical genre categorization/nomenclature and pushes us to introduce new terms in genre theory such as the notion of the canon genre and even the concept of anti-genre ${ }^{4}$ which will be dealt furtively in this paper. Second, it attempts to study its degree of influence on modern young adult literature represented by Midwinter Blood and in Darkness both Winners, successively, of the 2013 and 2014 Michael L. Printz awards.
\end{abstract}

If we question/deconstruct the discourse in the Foucauldian sense in order to find the absence that is hidden by the presence we may come to the conclusion that Midwinter Blood and In Darkness revolve around a few themes and three major literary techniques.

Keywords: Canon Genre; Anti-genre; embedded narrative; narratology; Iconicity

\footnotetext{
${ }^{1}$ On July the $20^{\text {th }}$, 1994, Jacques Derrida received a letter from Maurice Blanchot in which Blanchot declares, "Fifty years ago, I knew the happiness of nearly being shot to death."See Derrida (2000:47) and Blanchot Maurice (2000:9) See also Derrida's comments on Blanchot's letter: "When one is dead, it does not happen twice, there are not two deaths even if two die [...] I am not dead and I am dead. At that instant I am immortal because I am dead: death can no longer happen to me." Demeure, pp. 67 and 68.

${ }^{2}$ Kristeva's coinage of the term "intertextuality" is an attempt to merge Ferdinand de Saussure's semiotics - his study of how signs derive their meaning from relationships of difference — with Bakhtin's dialogism—-his examination of the multiple meanings, or "heteroglossia" of an utterance. See Hutcheon, Linda(1985)

${ }^{3}$ Kendall and Wickham outline five steps in using "Foucauldian discourse analysis". The first step is to recognize that discourse is a sum of regular systemic statements. The subsequent steps are based on the identification of rules on:

- $\quad$ how those statements are created;

- $\quad$ what can be said (written) and what cannot;

- $\quad$ how spaces in which new statements can be made are create

- $\quad$ Making practices material and discursive at the same time.

${ }^{4}$ Consider the nativity stories genre and the Muslim and Jewish accounts about this nativity. Clearly, we may consider the latter(Muslim and Jewish accounts) as anti-genres since both religions deny the cross.
} 


\section{Memory/reminiscence theme}

Both books are about fissured reminiscences or what Sedgwick (Midwinter Blood) cogently describe as "the images that swim through the head-they are the broken pieces of fractured memories". Broken memories throughout the two books hide other broken memories ,and it is the fate of many characters in the two books to be like "a ghost drifting over the face of the earth, rootless" ( Midwinter Blood,first part).Consequently, it is the responsibility of the reader to reconstruct the pieces of the puzzle and reach the end which is the beginning in fact with some clues, some logical explanations with which he or she is able to close the " gate between our world and the world of the Lwa" (In darkness). Indeed, Levi Strauss is quiet right when he says that the critic/reader always puts something of himself into the work he/she reads. But this addition should not be too structuralist or in Genette's (1980: 161-211) words "at the level of the sentence" but rather at the level of "the 'large unities' of discourse, beyond the framework - which linguistics in the strict sense cannot cross - of the sentence."

If we adopt Lacan's discourse of the analyst, as opposed to the discourse of the hysteric for example ${ }^{5}$; we may be able to see that both Marcus Sedgwick and Nick Lake have drawn two unfinished maps and it is the responsibility of both protagonists/ readers to fill up the gap, gather patiently the few clues thrown here and there and build this puzzle upon which their lives depend. Similarly, In the Arabian nights, though in a reverse way and hence in anti-genre fashion, Shahrazad is constantly creating more narrative puzzles to escape her gruesome fate (decapitation if she fails to entertain the king) in the morning. Indeed, the map metaphor may be the most accurate description of this Hitchcockian embedded suspense for the simple reason of being mentioned in both books. In "in Darkness", Shorty was able to draw the map of Soley 19, "while he would make a map of Boston only he didn't know anything there so it was a very blank map." While in "Midwinter Blood" Eric was able to identify the missing Western part of the island from the map that Tor gave him before: "into his memory comes the image of the map of the Blessed.... Only the Eastern half of the island is printed"

Digging through memory is painful (in Darkness) or perilous (Midwinter blood). Of course memory makes us human and as the young Shorty aptly says in "in Darkness", "The sea does not want to remember". Only humans want to remember and only humans develop strategies to fight remembrance. Toussaint (in Darkness) for example decided not to sleep, or minimize his sleep -just three hours-"for when he slept, the dream would come. Turn him into a young man in a strange version of Haiti."

In Blessed Island (Midwinter blood) what is better than tea to make Eric "lose truck of time" and make "the forgetting begin again." While in Nick Lake's book "Boukman was destroyed not once but twice: a death in the world and a death in the memory."

Nonetheless, human agency and the struggle to remember and therefore find answers are prominent in both books. For instance, In "Midwinter Blood" Eric receives an interesting note from Merle:" Wake up and remember. You were right. The answer lies beyond the hill." While in "in Darkness" Shorty experiences moments of illumination such as when he says, "in my head a film started-Flash. Papa and manman ${ }^{6}$ arguing about Aristide,"etc...

At its basic level, memory has a triangular pattern made out of three basic components: Encoding, storage and retrieval. The disruption in this triadic relationship introduces us to two opposite concepts: what I call mythogenesis (formation of myths) and historicity (authentic history).

The two books are based on two iconic history figures. In "In Darkness" we are introduced to the great Toussaint de L'ouverture or the Black Napoleon of the Haitian revolution'. He and before him George Biasseau ${ }^{8}$ and Jean Francois ${ }^{9}$ were key figures in transforming an entire society of slaves into the independent state of Haiti. L'ouverture military skills and political strategies catapulted him into the leadership of the slave rebellion that was eclipsed in 1802 by the white Napoleon who imprisoned him in the notorious jail of Fort-de-Joux in Eastern France.

\footnotetext{
${ }^{5}$ For a clearer explanation see Mark Bracher. "On the psychological and social functions of language: Lacan's Theory of the Four Discourses" in Mark Bracher (ed) (1994:107-128)

6 "Maman" in French becomes "Manman" in Haitian Creole.

7 His military genius and political acumen transformed an entire society of slaves into the independent state of Haiti. The success of the Black revolution shook the institution of slavery and paved the way for slaves' emancipation throughout the world. Inspired by the French revolution, these few free people of color opted initially to fight for the expansion of their rights and the humanitarian handling of slaves. And only two years later, were they willing to combat the institution of slavery as a whole.

For further information see Mathewson (1982: 148-154) and Bell (2008: 3-4).

${ }^{8}$ Georges Biassou (1741, Haiti- 1801, Saint Augustine, Florida) was an early leader of the 1791 slave revolution in Saint-Domingue that began the Haïtian rising. he was prophesied by the vodou priest, Dutty Boukman, to lead the revolution.See Berlin, Ira (1998: 306-307)

${ }^{9}$ Jean-François Papillon (died 1805), was an African-born slave who had worked in the plantation of Papillon in the last decades of the 18th Century, in the North Province of Saint-Domingue. He escaped from that plantation and became a maroon, so when the Haitian revolution started in August 1791 he had already enjoyed a direct experience of freedom. See Saint-Remy, Joseph (1850: 22)
} 
In "in Darkness", Nick Lake, the scriptor, explicitly admits in the author's note that he has "embellished the details for his own purposes" The mythogenic depiction of this great leader is highly exaggerated or at least too perfect to be true. Suffice to say, for instance, that it was George Biasseau and not him who were prophesied by the Voodoo priest, Dutty Boukman, to lead the revolution. Actually, Toussaint did not take part in the earliest stages of the rebellion, but rather opted to wait a few weeks (some sources say even months) until he sent his family to safety in Spanish Santo Domingo. Moreover, we should not forget that surviving legal documents show him briefly renting a small coffee plantation worked by a dozen slaves.

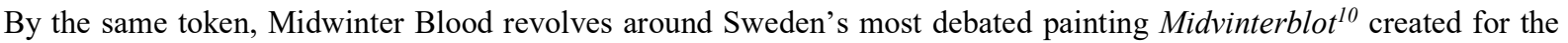
hall of the central staircase in National museum in Stockholm by the Swedish painter Carl Larsson in 1915. The painting portrays a legend from Norse mythology in which the Swedish king Domalde and not Erictus was sacrificed in order to prevent a food crisis. King Domalde left a child, Domar, whose reign was prosperous.

Carl Larsson and not Eric Larsson spent years working on his masterpiece and the painting was a fourth version and not hastily drawn in half an hour as it is claimed in "Midwinter Blood."

Such a floating of Grice's famous maxim of quality, from a strictly historical sense, paves the way towards the concept of Mythogenesis by dint of which the artist is able to create or reinvent a myth. In 'in darkness' the author creates a new Haiti divided between Route 9 and Boston, a perfect hero bestowed with "a sudden acquisition of the ability to read and write "who is like a Nostradamus able to see the future 200 years ahead and then like a super god/ Lwa, able to "ride like a horse" first Dread and then the young narrator of the story.

Similarly, Marcus Sedgwick (Midwinter Blood) creates a mysterious island where people possess "the elixir of eternity" and where inhabitants, at least the major characters Eric, Merle and Tor, are able to live seven lives following the Hindu tradition of reincarnation.

It is worth noting here that in their attempt to re-mythologize an ancient pagan myth, both writers could not escape the mythogenic traces of their Christian mythological backgrounds. In "in Darkness" Toussaint de l'ouverture ends like Jesus "crowned with thorns" while "in Midwinter Blood", in the book titled Unquiet Grave, Merle promises her lover that if she "has to wait for a year and a day, if she has to move the mountains... She will have a way for them to be together again." Notice two things, first the clear reference to Matthew 17:20 when Jesus declares that faith can move the mountains and second the explicit reference to "One Thousand and a Night."

Lastly, from a strictly narrative point of view, memory and its derivatives/synonyms and antonyms abound in both books and they function as Leitwortstil ${ }^{11}$. Indeed, the German word Leitwortsil that refers to the repetition of a wording, often with a theme, in a narrative to make sure it catches the reader's attention; is one of the most prominent literary techniques used in the two books.

In the Arabian nights Shahrazad developed the technique of thematic patterning ${ }^{12}$ to extend and therefore win precious time-the only possible way to escape an imminent decapitation in the following morning. According to Pinault (1992: 22) Thematic patterning means the insertion of a recurring motif in a narrative. Thus, Shahrazad's embedded stories that seem to have no end has a, in a way, a therapeutic function as the mysterious tea in Midwinter Blood that seem to provoke oblivion and insensibility. Indeed, Shahrazad does not attack the mind of her king by using some magic potions but rather attempts the impossible by attacking the notion of time itself. We all know that if we stood still in a flat Cartesian space the (y) axe that represents time will keep moving upward. One Thousand and a Night, attempts counterintuitively of course, to contract time by actually extending it.

Moreover, this notion of mixing between fiction and reality, mythogenic history and historicity is following a longstanding Arab Nights' technique whereby completely fictional characters such as Scheherazade,_Shahryār,_Ali Baba, and Aladdin coexist with real historical figures such as Al-Mustansir,_Abu Nuwas etc. One of the major effects of such a technique is the creation of a realistic "state of becoming" in the Deleuzian sense ${ }^{13}$. Shahryār, without even realizing it, is on the verge of a painful epiphany from which he leaves the flatness of a vengeful character to the roundness of an enlightened one.

${ }^{10}$ Midvinterblot (Swedish for Midwinter's sacrifice) is a painting created for the hall of the central staircase in National museum in Stockholm by the Swedish painter Carl Larsson in 1915. It is Sweden's most debated painting. For further information see Gunnarsson (1992) and especially Moynihan, Michael (2007: 236)

${ }^{11}$ See Pinault, David (1992: 18)

12 Thematic patterning is evident in One Thousand and One Nights, an example being the story of "The City of Brass". According to David Pinault, the overarching theme of the tale is that "riches and pomp tempt one away from God". The story is about a group of travelers who roam the desert in search of ancient brass artifacts. The narrative is interrupted several times by stories within the story. These include a tale recorded in an inscription found in the palace of Kush ibh Shaddad; a story told by a prisoner about Solomon; and an episode involving Queen Tadmur's corpse. According to Pinault, "each of these minor narratives introduces a character who confesses that he once proudly enjoyed worldly prosperity: subsequently, we learn, the given character has been brought low by God ... These minor tales ultimately reinforce the theme of the major narrative". See Heath, Peter (1994: 358-360)

${ }^{13}$ Deleuze notes, 'becoming isn't a part of history; history amounts only [to] the set of preconditions, however recent, that one leaves behind in order to "become", that is, to create something new.' Cited in Craig, Lundy (2012: 216) 
In order to consolidate this overarching theme of memory versus reminiscence Marcus Sedgwick and Nick Lake produced at least three prominent subthemes and a variety of literary techniques directly borrowed from One Thousand and a Night.

\subsection{The theme of sacrifice}

The theme of sacrifice permeates both books from beginning to end but I opted to consider it as a subtheme for at least one reason. Sacrifice as a ritual performed to appease an angry god or break a curse is never pictured in the three books as an end by itself-It is rather a last attempt to resolve what is seen as a helpless case, or a vengeful response to a harm committed. In One Thousand and a Night the very notion of sacrifice is subtly criticized and even ridiculed.

In Midwinter Blood, the act of sacrifice is no longer a sacrifice in the ritual sense but rather an act of vengeance against both lovers. After all, Merle was killed because she slashed the face of Tor and the executioner. The writer in a way, by dramatically staging such an absurd killing (why Merle if all they need is the death of Eric to bring back rain); seems to suggest that at the deepest level, all sacrifices are performed for humans and not gods.

Indeed, sacrifice -devoid of any ritualistic overtones-is almost everywhere in "Midwinter Blood". Eric as a case in point sacrificed himself at least three times in the book: he embraced the bomb in the Archeologist, "stoved in" his boat and "drowned himself" in the Unquiet Grave and finally Offered his life for the life of David in The Airman.

It is worth noting at this juncture, that the Airman scene is one of the strongest dramatic moments related to sacrifice. Before his death, Eric asks David, "Your daughter-how old is she?" Then later in the narrative, we learn that the favorite story of David's daughter, the twelve-year-old Merle, is about Eric's heroism.

Similarly, but with a less dramatic intensity, in 'in Darkness', the young Shorty resorts to the Lwa as a last attempt to get out of the dark cave he is entrapped into. Notice that at nowhere by the end, the protagonist suggests a miraculous link between the sprinkling of blood from his wrist and the coincidental appearance of the rescuers. However, the supernatural element is exacerbated when Toussaint declares in "in Darkness" that "he lived and died so many times for this country" while Dread Wilme "walked down the street with a thousand bullet holes in him" and saves the young Shorty from imminent death.

It is important to point out that the thematic patterning of sacrifice is enhanced by the word "blood" which functions as a leitwortsil in the two books. In "in Darkness", the young Shorty, for instance, kept alive "cos of drinking the blood". Ironically, all his endeavors throughout the book are to escape his gruesome destiny foretold by the Houngan: "you will end in blood and Darkness."

Midwinter Blood signals the leitwortsil right from the title. Later in the narrative we understand the linguistic origins of the word 'bless' is in fact (blot or blood). Likewise, Tor-the blood thirsty vampire- looked at the twins "the way a wolf wants meat" while Eric is constantly fighting "blood-soaked dreams of another time, of another place. Another life."

The theme of sacrifice in the Arabian Nights is signaled right from the beginning. The plot of the story can be summarized in a few words. A Persian king Shahryār gets jealous and angry when he discovers that both his brother's wife and his are unfaithful. In a furious spree of revenge, the king begins to marry a succession of virgins only to execute each one the next morning. It was the duty of the vizier, Shahrazad's father, to provide the blood thirsty king with a virgin every night. The young virgins of his kingdom were about to disappear if someone does not provide a solution. The brave Shahrazad offers herself as the next bride and the Vizier reluctantly agrees after He tells her the story of the donkey and the ox in hope she changes her mind. Shahrazad refuses to be intimidated and uses the wits of her literary mind and by the end of the book prevails (becomes the only wife to the king who falls in love with her) though she faced imminent death every night she told her king a story. It is worth noting at this juncture that sacrifice as a ritualistic social behavior performed to appease the anger of men is treated in a very cynical way in the Arabian Nights. As a case in point, in the narrative titled "The Story of the First Old Man and of the Hind" the book clearly criticizes the validity of shedding blood in order to appease gods or celebrate the feast of a Bairam. ${ }^{14}$

The story located in chapter 3is about an old man who decides to adopt the son of his servant since his wife could bear him children. The wife got jealous, learnt black magic and transformed the son into a calf and the slave into a cow. When Bairam feast came the narrator says: "To celebrate it I ordered my steward to bring me a very fat cow to sacrifice. He did so. The cow that he brought was my unfortunate slave. I bound her, but just as I was about to kill her she began to low most piteously, and I saw that her eyes were streaming with tears. It seemed to me most extraordinary, and, feeling a movement of pity, I ordered the steward to lead her away and bring another. My wife, who was present, scoffed at my compassion, which made her malice of no avail. "What are you doing?" she cried. "Kill this cow. It is the best we have to sacrifice....the steward killed the cow" but on skinning her found that she was nothing but bones, although she appeared so fat." The old man was vexed and ordered his steward to bring another suitable animal." In a short time he brought a very fat calf, which, although I did not know it, was my son. It tried hard to break its cord and

${ }^{14}$ Eid al-Adha "Festival of the sacrifice", also called the Feast of the Sacrifice or Bayram in Kurdish/Turkish and Indian languages. It celebrates and honors the willingness of Abraham (Ibrahim) to sacrifice his promised son, Ishmael (Ismail), as an act of submission to God's command, before God then intervened, through His angel Gabriel (Jibra'il) and informs him that his sacrifice has already been accepted. 
come to me. It threw itself at my feet, with its head on the ground, as if it wished to excite my pity, and to beg me not to take away its life."

The story goes on until the steward's daughter informs the old man that the calf was his son and that she is able "At these words, of Genius," continued the old man, "she could change his son back to his proper shape", if he agreed to give him to her as a husband ${ }^{15}$. The old man "agreed with all his heart, and I promised to give her an ample dowry. " The Steward's daughter transformed the mean wife into a Hind and she lived happily with his handsome son. The narrative finishes when the old man asks the genius to whom he was telling his story:"is this not a most marvelous tale". Then, another story begins etc...

\section{Theme of restlessness/edginess}

The theme of restlessness or living on the edge depicts every major character in the two books "ready to bounce and land somewhere "16 as D.H Lawrence once put it. Dramatically speaking, "the restlessness inside stillness inside restlessness" follows the embedded narrative of a story within a story.

The spatial and time vectors are skillfully exploited in both books to convey this notion of edginess, of being on the brink of something about to happen or in the words of the young Shorty in "In Darkness", "all set to open up the gate between our world and the world of the Lwa."

Indeed, in "In Darkness", the family of the unfortunate Marassa lives in the" no man's land" between route 9 and Boston- a few strides from both enemies. Similarly, the old Haiti of Toussaint is divided between the free rebel half led by L'ouverture and the Guildive under British control.

In Midwinter blood, all the seven lives are led in the same spot in the island: "the last house on the right before the top", a stone's throw from the forbidden western half: "the very center of the island' as Tor pointed out to Eric right from in the beginning of Midwinter Blood.

According to psychoanalytic theory, temporality only exists in the psychic of the characters. In "in Darkness", the time vector is a mixture between now and then, present and past, dream and reality.

In "Midwinter Blood", apart from this duality between binaries, the time vector runs through centuries to describe the seven lives/ incarnations of at least three major characters in the story: Merle, Eric and Tor.

However we should not forget that this seemingly avant-gardist approach in narratology echoes One Thousand and a Night. Shahrazad does not in fact live in the present (time of narration) but rather in the future (time of possibility) as she shrewdly tells her king: "What is this compared with what I shall tell you tomorrow night if the king spares me and lets me live?" In consequence, Shahrazad's cliff hanger technique ${ }^{17}$ succeeds in extending her life every night for another dawn by arousing the king's curiosity and suspense to see her the next night to finish the story.

Topologically, the Arabian Nights stands at midpoint between East and West. It is a common misconception that One Thousand and a Night is an Eastern work of art. The Arabian Nights themselves trace their roots back to ancient Persia. True, some stories are definitely Arabic in frame and content and were originally folk stories from the Caliphate era, but many others, especially the frame story, are most probably drawn from the Iranian Hazār Afsānn. ${ }^{18}$

The idea behind this short historical reference is that if language influences thought then it is safe to infer that the Arabian Nights is a true bridge between the Semitic languages of Mesopotamia and the Indo European languages of the West $^{19}$.

In a way Young's discovery of the similarities between Indian, Iranian and European languages in 1813, explains perfectly well the unparalleled success of one thousand and a night in East and West.

${ }^{15}$ Notice how Shahrazad implicitly prepares her king to accept the idea of marrying her, the daughter of his vizier, if man of his rank is ready to marry his concubine slave. Though the book describes a vengeful sadist king I believe Shahrazad was in love with him right from the beginning of the tale. This love may be explained by the fact that Shahrazad was too smart not to notice some potential in her king.

16 'Oh, it doesn't matter,' said Gudrun, somewhat superbly. 'If one jumps over the edge, one is bound to land somewhere." Women in Love, chapter one.

${ }^{17}$ A cliffhanger is a type of narrative or a plot device in which the end is curiously abrupt so that the main characters are left in a difficult situation without offering any resolution of conflicts. Such a suspenseful technique is used largely in fiction as in movie serials and television series.

18 A Pahlavi Persian work Hazār Afsān (Persian: هزار افسان, lit. A Thousand Tales) that is a collection of folklore tales that probably have some Indian elements. See Marzolph (2007).

19 It was Thomas Young who in 1813 first used the term Indo-European, which became the standard scientific term through the work of Franz Bopp, whose systematic comparison of these and other old languages supported the hypothesis. A synonym for "Indo-European" is Indo-Germanic (Idg. or IdG.), which defines the family by indicating its south easternmost and north westernmost branches. In most languages this term is dated or less common, whereas in German it is still the standard scientific term. Advocates of Indo-Germanic often claim that "Indo-European" is misleading because many historic and several living European languages (the unrelated Uralic languages, as well as several others, are also spoken in Europe) do not belong to this family. Advocates of Indo-European counter that Indo-Germanic is misleading because many of the European languages included are not in fact Germanic.

See Robinson, Andrew (2007) 
But what interests us here is that the book, spatially and temporarily stand in a midpoint between two different worlds which reminds us of the no man's land mentioned earlier.

Lastly, it is worth noting that this notion of edginess is generally triggered by a desire to escape darkness and caging. The house where Eric was given hospitality is named "the claw" and the first advice/ order given to Eric by Tor as soon as he set foot on Blessed island in "don't go far". But Eric whose "much of his life is spent travelling, investigating stories all over the world" is not ready to succumb to the caging suggestions of the ward/high priest for the reason that "maybe he is never satisfied."

In "In Darkness", Shorty is trapped under the rubble of the 2010 Haitian earthquake, trying desperately to escape the gothic prophecy of the Houngan: "you will end in blood and darkness". Correspondingly, In the Arabian nights, Shahrazad's main intention is to break the cycle of death/revenge that jeopardized the very existence of the beautiful virgins in her kingdom.

\section{Fate/ destiny theme}

From a philosophical point of view fate is different from destiny. Fate ${ }^{20}$ in simple terms refers to the deterministic itinerary that an individual has to follow. Destiny ${ }^{21}$, at least according to Arthur Schopenhauer (will to live) and Nietzsche (will to power) is linked with human resolve and agency.

Both concepts are explored thoroughly by Marcus Sedgwick and Nick Lake. In Midwinter Blood, when Eric asks Merle this existentialist question: "This is ridiculous, have we done this before?" Merle strongly defends the notion of fatality using seemingly logical arguments," why is it? Why is it any more ridiculous than a thousand things? The earth spins around the sun ...water can eat a mountain away...It's just how it is."

However, in "In Darkness" the concept of fatality is treated at a deeper level. Toussaint for example, grimly says that "We are all trapped in a cave and that cave is ourselves". Indeed, he seems to repeat like a mantra that "behind the mountain there is another mountain; behind the fire there is another fire" etc...Similarly, the young Shorty wonders "if the dead will be reunited... Or everything would stay broken and never be made whole." In one of the various moments of false epiphanies, Shorty thinks that his "Manman (maman) was wrong. I think everything comes back-that's what is so fucked up about the universe." 22

Paradoxically, in trying to fulfill or succumb to the determinism of their fate the protagonists in both books are actually destroying the walls of fatality and creating their destiny. In Midwinter Blood, Eric is conducting an almost criminal investigation to understand/explain the strange/odd/ disturbing/unsettling world of Blessed Island. At the end of every analysis, his archenemy is not Tor but rather that bloodthirsty god who seems to adore royal blood. By the end/beginning of the book Merle slashes the face of Tor and the executioner and helplessly tries to escape with Eric a very atrocious fate. Both protagonists end up dying together to be "no longer in love " but " love itself" and consequently create a new fate that begins with the famous leitmotif "so, it is/goes."(Notice that the phrase is taken from Kurt Vonnegut's novel Slaughterhouse five ${ }^{23}$ )

In "in Darkness", the young shorty and before/after him Toussaint seem to grapple with this Legba, or god of war "that came all the way from Africa to live" in a smooth small stone. The book begins with a desperate cry for help: "I am the voice in the dark, calling out for your help." And ends with a solemn prayer and an implicit recognition of the main character's feebleness in front of this god he constantly doubted the power. Instead of being a constantly divided Marassa, doomed to die "in darkness and blood" his soul rejoins Toussaint's and becomes whole again: "he was in darkness, but now he is in light"

Similarly, In the Arabian Nights Shahrazad's fate is to die the next morning like every beautiful virgin in her kingdom. But her destiny or more precisely agency was that through storytelling and the masterful use of cliffhanger techniques she was able to reinvent the determinism of her fate and win the heart of her lunatic king. Throughout the whole embedded stories of the Arabian Nights one may notice a recurrent theme that almost functions like leitmotif: the triumph of the good, the rise of the humble and the marriage of the concubine with her master. Seen from this perspective, the Arabian Nights may be considered the first implicit criticism of the strongly and religiously sanctified institution of Harem and polygamy.

\section{Literary techniques used by Nick Lake and Marcus Sedgwick.}

\section{The unreliable narrator.}

An unreliable narrator is a term first referred to by the great critic Booth (1961) in his "the Rhetoric of Fiction"24. It refers to a narrator whose credibility is seriously compromised. According to Booth, most of the time the narrator's unreliability is not explicitly indicated but rather hinted at. Attempts have been made at a classification of unreliable

\footnotetext{
${ }^{20}$ See Lisa Rapahals (2003: 537-574)

${ }^{21}$ See Dietrich (1962: 86-101), Karamanolis (2000: 610-611) and Nagel Thomas (1987) especially chapter 6.

${ }^{22}$ Notice the curious mixture of both Absurd and existentialist schools of thought.

${ }^{23}$ Vonnegut's well-known phrase "so it goes", is a well-known expression used by Vonnegut to satirize death in Slaughterhouse-Five. Mark Feeny (2007) says in the Boston Globe the following: "Its combination of simplicity, irony, and rue is very much in the Vonnegut vein".
}

${ }^{24}$ See Booth, Wayne (1961: 158-159) 
narrators. As a case in point, William, Riggan (1981) enumerated in his study various types of unreliable narrators, focusing on the first-person narrator as being the most common kind of unreliable narration.

This technique is expertly employed by Nick Lake for at least two reasons. Firstly, it is used as a dramatic hook to attract the reader's attention and interest to its maximum and secondly, to strengthen the verisimilitude of a dramatic narrative narrated by a fifteen -year-old kid under the insurmountable pressure of terror and darkness.

Following Riggans' insights the young shorty, may be viewed as representing both The Madman and The Naï. In many instances of the narrative, Shorty explicitly indicates that "he is aware that he is getting mad." His naivety is definitely highlighted when he says," I'm still not 100\% convinced that I'm not a ghost, that this not the land under the sea, where the dead go."

In Midwinter Blood, Marcus Sedgwick exploits the technique of unreliable narration in a more extensive fashion. In order to increase the dramatic intensity and the suspenseful/ghostly tone of his tale, He relies heavily on what Nunning (1998) calls "signals of unreliable narration" 25 . As a case in point, in the "Unquiet Grave" part 5, Merle, the ghost, introduces herself to the unsuspecting twins as Laura, "who their parents had arranged to look after them." She mesmerizes the unsuspecting twins with her kindness, beauty and her extraordinary ability to tell "stories full of adventure of trips to mysterious lands, of brave heroes and wicked villains." By the end of Book Five, we, readers, realize her narrative Heist and our thrill reaches its peak when we discover two surprises. On the one hand," the boards are wet at the foot of the bed" and on the other hand Eric is in fact a "she" named Erica.

In the same way, in the Arabian Nights the technique of unreliable narrator is used extensively to generate mainly not only suspense but also time dilation. We should always remember that Shahrazad is under constant threat of death if she does not recount a beautiful tale to her king every night until the rooster crows at dawn. The examples abound in the book but suffice to take the story of the "The Three Apples" and" the Seven Viziers" as examples. The tale of the "Three Apples" may be considered an early murder mystery ${ }^{26}$, in which two men claim to be the murderer, but only one is telling the truth. In the other story titled "The Seven Viziers" a woman of loose behavior accuses a young handsome prince of assaulting her. The Seven Viziers tells seven different stories to prove that the courtesan's allegations are false but the woman narrates a story to prove the unreliability of the viziers.

\subsection{Embedded narrative}

Nested narrative ${ }^{27}$ (a story within a story) technique is heavily used by Marcus Sedgwick and Nick Lake. The French has a term for such a technique: "mise en abyme" ${ }^{28}$ which literally means "placement into abyss." The term is taken from heraldry and it refers to a large image that contains a smaller copy of itself, in a sequence appearing to recur infinitely.

In a way," In Darkness" typifies this French view of embedded narrative. The reader is divided between two worlds, the now of Shorty and the then of Toussaint. Various types of deixis are extensively used in the book: Deixis of place (all action happens in Haiti), time (all protagonists in the book experience a dream-like back and forth travel in time), person (in both books, protagonists are referred in a very mysterious way: In 'Then' L'ouverture constantly dreams of "this young boy" whereas in 'Now' Toussaint is considered as an icon or a Lwa.) Apart from adding strength to the organic unity of both plots, Deictic expressions reminds the reader that he/ she is in fact in the same world of narration, in a place where , in the words of Shorty, "there is no future and no past." The fact that deixis technique is not extensively used in "Midwinter Blood" does not mean that pronoun deixis do not have any function in the book. Indeed, the pronoun 'you' has almost magical overtones in "Midwinter Blood" -it refers to Merle and Eric interchangeably.

However, in Midwinter Blood, the story within a story technique is explicitly revealed in the action of the plot of the outer story. Like Edgar Alan Poe in "the Mad Trist" or even Don Quixote of Cervantes, the protagonists' actions are influenced by the nested stories within the narrative. A brilliant example borrowed from Sedgwick's book is when the painter adds the "the distinct face of Merle" after twenty five years of artistic barrenness. If Merle did not offer the first apple, the Dragon man would have died in grief, no doubt, and the face of little Merle would not have added hope to the grim sacrificial ceremony of the king's death in Midvinterblot.

It is worth noting at this juncture that Genette's suggestion that the presence of narrative embedding is one of the formal criteria for differentiating fictional from factual narratives ${ }^{29}$ may perfectly apply to both books but is too narrow to fit the narrative technique used in The Arabian Nights. The main reason for this argument is the fact that in the "Arabian Nights" the outer story is related by an unknown narrator, and inside the frame of this narration the stories are told by Shahrazad. The Arabian nights are based on stories narrated within stories and even within these narrated stories there

\footnotetext{
${ }^{25}$ According to Nunning (1998), there are a number of signs that constitute or hint at a narrator's unreliability. Nünning has suggested dividing these signals into three broad categories: Intratextual, extratextual and Reader's literary competence.

${ }^{26}$ See Pinault, David(1992)and Marzolph, Ulrich (2006)

${ }^{27}$ An embedded narrative usually comprises the majority of the text, while the framing narrative occupies just the first and last few pages.

${ }^{28}$ See Dorrit Cohn and Gleich (2012: 105-114)

${ }^{29}$ For Genette, narratology is the study of the internal mechanism that governs both factual and actual narratives. See Genette, G $(1972,1980,1983)$
} 
are some other stories. ${ }^{30}$ Additionally, Inside some of these primary or minor stories we may find actual historical figures such as the two kings Al Mustansir and Harun Al.Rashid, poets such as the hedonistic poet of that time Abu Nuwas $^{31}$ and even famous women such as the beautiful Shirin, the wife of the Sassanid King Khosrau the second. Instances of narrative embedding abound in the Arabian Nights - suffice to give a random example such as the story titled "Adventure of the Caliph Harun Al-Rashid". The king, disguised as a merchant meets three strange persons: an old man, a young man and Cogia Hassan. The three men narrate three different stories. But within these stories there are other minor stories. This labyrinthine type of contracting time by dividing it into chunks and therefore actually extending it is one of the unparalleled techniques used in "One Thousand and a Night"

4.2 Flash backs/flash-forwards.

Obviously this literary technique is one of the major narrative techniques in both books.

In "Midwinter Blood" and in "In Darkness", internal analepsis versus external analepsis ${ }^{32}$ are used for at least three reasons. Firstly, both techniques are used to strengthen suspense and increase the readers' involvement. Secondly, they are efficiently used to develop the major characters in both narratives (Shorty, Toussaint, in In Darkness, and Eric, Merle and to some extent Tor in Midwinter Blood). Lastly, the techniques are employed to add structure to the narratives that both started in Medias res. ${ }^{33}$

It is useful to add at this juncture that foreshadowing and flashbacks have other minor techniques that buttress their effects and highlight their propensity.

Among these minor techniques is what is known as Chekov's gun. Chekov ${ }^{34}$, one of the greatest short story tellers in the world says that if a writer mentions more than twice a rifle it has to fire later in the narrative. This Hemingwayan technique of brevity and precision is present in many instances of the two narratives. In "Midwinter Blood", expressions such as "so it is "or words such as "hare" are literally everywhere in the narrative. Though the book deliberately warps the notion of time and space, the linearity of characterization; the reader does not need to guess to discern who speaks, or to doubt if he / she is reading a totally different story.

In "In Darkness" a good instance of such a technique is when Shorty describes how" he would "click his tongue against the roof of his mouth". Later in the narrative, we discover that Toussaint has the same behavior whenever he is thirsty or thinking. True, these small details appear at first trivial and sometimes even absurd but as we go further in our reading experience we discover that no word is put randomly. Both books share this high quality of good literature that at some moments, we readers, will be at a loss if a single word is altered from where it is supposed to be.

Similarly, One Thousand and One Nights contains "repeated references to some character or objects which appear insignificant when first mentioned but which reappears later to intrude suddenly in the narrative." A notable example is in the tale of "The Three Apples." ${ }^{35}$

Another minor technique explored by both writers is known as the Ticking Clock scenario which refers to an impending threat that tangibly jeopardizes the life of one or many characters in the fiction. In Midwinter Blood a good example may be drawn from the Archeologist when the writer speaks about a bomb at the end of Chapter 8: "It will be a mere sixty years old and it will be lethal." In the end of chapter nine he continues this technique saying," now, almost half exposed, the back end of a bomb hangs above his head."

In "in darkness", one of the best examples is when shorty says: "I don't know how much time I have to tell my story."

30 One of the Arab books that perfectly uses this technique is Ibn al-Muqaffa's translation of the Kalīla wa Dimna from Middle Persian considered by Wacks as "the first masterpiece of Arabic literary prose" . See Wacks(2003: 178-189) and lane Andrew (2003)

31 Abu Nuwas is considered one of the greatest poets of classical Arabic literature. He influenced many later writers, such as Omar Khayyám, and Hafiz — both of them Persian poets. A hedonistic caricature of Abu Nuwas appears in several of the Thousand and One Nights tales. Among his best known poems are the ones ridiculing the "Old Arabia" nostalgia for the life of the Bedouin, and enthusiastically praising the up-to-date life in Baghdad as a vivid contrast. See Kennedy, Philip (1997 and 2005)

${ }^{32}$ A form of flashback in which earlier parts of a narrative are related to others that have already been narrated In literature, internal analepsis is a flashback to an earlier point in the narrative; external analepsis is a flashback to a time before the narrative started. See Jung (2010)

33 A Latin expression that refers to the artistic technique of starting the action of a story from the middle. See Shakespeare's "tempest" as a good instance of such a technique.

${ }^{34}$ See valentine (1987) and Mikhailovich (1983)

35 The Three Apples (Arabic:التفاحات الثناثة) is a story contained in the One Thousand and One Nights collection (also known as the "Arabian Nights"). It is a first level story, being told by Scheherazad herself, and contains one second level story, the Tale of Núr al-Dín Alí and his Son. It occurs early in the Arabian Nights narrative, being started during night 19, after the Tale of Portress. The Tale of Núr al-Dín Alí and his Son starts during night 20, and the cycle ends during night 25, when Scheherazade starts the Tale of the Hunchback. See Pinault, David(1992: 86-97). 
Linked to this technique, though slightly different, is what is called cliffhanger. Both writers make extensive use of such a technique. For instance, Nick Lake ends his 'Then' chapter in the following way: "then something snapped and he..." but leaves the reader eager to go to the next chapter in order to satisfy his/her curiosity. Similarly, Sedgwick finishes for instance part one saying, "A final thought bleeds into it, following on from so very many strange thoughts. I think Eric Seven, have lived this before." Deliberately, both writers withhold vital information right at the end of their chapters. The same technique is used by the famous Shahrazad, who is facing a morning execution on the orders of her master, King Shahryār, devises the solution of telling him a story but leaving it at a cliffhanger, thus forcing the king to postpone her execution to hear the rest of the tale. She would typically tell a frame story then before reaching the climax she would tell another story and then another and only then, when dawn arrives and she hears the roaster crow she rushes to fill up the missing denouements in the different tales narrated but keeps the main story unfinished. Having wasted all the night expecting to find out the end of the main story, the helpless king has no option but to postpone the execution of Shahrazad in the hope that she would make a mistake in the next night. But Shahrazad never makes a mistake and tricks her king again and again.

Lastly, it is worth mentioning that we can link the ensemble of these primary and minor techniques with two concepts; Genette's notion of dramatic acceleration versus deceleration, and Bachtin's notion of heteroglossia that are quite popular among literary critic as well as discourse analysts.

To begin with, Genette's concepts of acceleration versus deceleration ${ }^{36}$ within the narrative are highly prominent in Nick Lake's book. The young Shorty and behind him the author's voice seem to admit, indirectly of course, unnecessary moments of deceleration in the pace of the narrative. He says in the middle of the narrative," Listen, I'm telling you all this for a reason... So you understand the routine..."

Likewise, the writer seems to be aware of the sudden acceleration in his narrative and again Shorty says," I have to tell you the rest quickly now..."

Lastly, by dint of going back and forth in time, both books typify Bakhtin's notion of heteroglossia. I personally think that the main strength in Nick Lake's book, In Darkness, is the creation of two different linguistic repertoires belonging to two different periods of time and two different age groups.

In the Arabian Nights, Genette's notion of discursive speed is present in almost every page. The five tempos are exploited to the limit of saturation and I'm not aware of any book that heavily explored this notion of time dilation other than Proust's novels perhaps. Probably it may be due to the simple fact that Shahrazad had basically two missions: To remain alive and make a ruthless cynical king discover the beauty of love and monogamy.

\section{Conclusion}

The Arabian Nights corroborate the validity of the notion of iconicity in Literature and humanities in general. Postmodern theoreticians especially if they are attracted by the principles of critical pedagogy, claim that all works of literature are the same and vertical categorization is nothing but a discourse of the powerful (Foucault) ${ }^{37}$ or those who have the power to be "listened to" usually impose the norms of reality and the official discourse (Bourdieu) $)^{38}$. These radical statements might have some truth but the Arabian Nights, the literary product of the most shunned and discriminated against race nowadays continues, paradoxically, to exert an extensive influence on literature. Clearly, Post-structuralist theory cannot answer convincingly this blatant contradiction unless it admits that canonicity may also be due to the greatness of a work of art such as the Arabian Nights.

\section{References}

Bartlett, Rosamund, and Anthony Phillips (2004), Chekhov: A Life in Letters. Britain: Penguin Books.

Bell, M.S. (2007). Toussaint L'Ouverture: A Biography", New York: Pantheon,Vintage Books.

Berlin, Ira.(1998). Many Thousands Gone: The First Two Centuries of Slavery in North America. Cambridge, Massachusetts: Harvard University Press, 1998.Pp. 306-307

Booth, W. C. (1961). The Rhetoric of Fiction. (University of Chicago Press.) pp. 158-159.

Blanchot, M. (2000). The Instant of my Death, trans. by Elizabeth Rottenberg. Stanford: Stanford University Press.

Craig Lundy (2012).History and Becoming: Deleuze's Philosophy of Creativity. Scotland: Edinburgh University Press.

Dorrit Cohn, Lewis S. Gleich. (2012).Narrative (Volume 20, Number 1, January 2012) pp. 105-114 .Ohio State University Press

Deleuze, Gilles. Foucault. (Minneapolis: University of Minnesota Press, 1988).

Gavin Kendall; GaryWickham (1999). SAGE.. Using Foucault's methods. February issue, 42.

Angelet, C. and J. Herman. (1987)."Narratologie", in M. Delcroix and F. Hallyn (dir.), Introduction aux études littéraires. Paris: Duculot.

Genette. G. (1980). Narrative Discourse: An Essay in Method, trans. Jane Lewin, Ithaca. New York: Cornell University Press.

Geggus, David (2002). Haitian Revolutionary Studies. Bloomington \& Indianapolis: Indiana University Press. p. 198.

${ }^{36}$ The two terms refer to the notion of discursive speed. Genette "elegantly proposes five canonical tempos, which he calls Ellipsis, summary, scene, stretch (slow motion) and pause". See Patrick, O’Neil (1994:44)

${ }^{37}$ See The excellent book written by Deleuze, Gille (1988)

${ }^{38}$ See Grenfell, M (ed) (2012) 
Grenfell, M. (2012). Pierre Bourdieu: Key concepts: Second Edition. London: Acumen Press.

Hutcheon, Linda. (1985).A Theory of Parody: The Teachings of Twentieth-Century Art Forms. New York: Methuen. Irwin, William. (2004). Against Intertextuality. Philosophy and Literature ,28, 227-242.

Jacques Derrida, (2000). Demure: Fiction and Testimony, trans. by Elizabeth Rottenberg. Standford: University Press. Karamanolis, George E. (2000).Stoics and Epicurians. Encyclopedia of Greece and the Hellenic Tradition.1, 610-611. Kennedy, Philip F. (2005). Abu Nuwas: A Genius of Poetry . London: OneWorld Press.

Lisa Raphals (2003). Philosophy East and West. Hawai'i. University of Hawai'i Press. pp. 537-574.

Moynihan, Michael (2007). "Carl Larsson's Greatest Sacrifice" in Buckley \& Moynihan eds. (TYR vol. 3. Atlata:Ultra Press.

Matthewson.(1982). Abraham Bishop:The Rights of Black Men, and the American Reaction to the Haitian Revolution, The Journal of Negro History, 67 (2), 148-154.

Marzolph (2007), "Arabian Nights" Encyclopedia of Islam I ( Leiden: Brill.)

Mark Bracher. (1994). Lacanian Theory of Discourse: Subject, Structure and Society. New York: New York University Press.

Moynihan, Michael (2007). "Carl Larsson's Greatest Sacrifice" in Buckley \& Moynihan (eds.), TYR vol. 3. Atlanta: Ultra Press

Nagel, Thomas (1987). What Does it all Mean? New York: Oxford University Press.

Pavis, Shantz (1998). Dictionary of the Theatre: Terms, Concepts, and Analysis. University of Toronto Press.

Pinault, David (1992), Studies in Arabic Literature. Story-Telling Techniques in the Arabian Nights, 15, 18.

Patrick, O’Neil. (1994). Fictions of Discourse: Reading Narrative Theory. Canada: University of Toronto.

Robinson, Andrew (2007). The Last Man Who Knew Everything: Thomas Young, the Anonymous Genius who Proved Newton Wrong and Deciphered the Rosetta Stone, among Other Surprising Feats. Britain: Penguin.

Riggan, William (1981). Pícaros, Madmen, Naīfs, and Clowns: The Unreliable First-person Narrator. Norman: University of Oklahoma Press.

Turner, Mark (1966).The Literary Mind: The Origins of Thought and Language .Oxford University Press. Great Britain. WACKS David.( 2003). The Performativity of Ibn al-Muqaffa "s "Kalīla wa-Dimna" and "al-Maqāmāt al-Luzūmiyya" of al-Saraqusțī . Journal of Arabic Literature, 34, 178-189. 